\title{
Isolation and characterization of denitrifying halophilic bacteria from Bahr Al-Milh Salt Lake, Karbala, Iraq
}

\author{
Maryam Hosseini, Mushtaq T Sh. Al-Rubaye*, Javad Fakhari, Fateme Babaha \\ Department of Microbiology, Faculty of Biological Sciences, Shahid Beheshti University, Tehran, Iran.
}

\section{ARTICLE INFO \\ Article history: \\ Received on: December 05, 2017 \\ Accepted on: January 29, 2018 \\ Available online: May 22, 2018}

\section{Key words:}

Halophiles,

Nitrate reductase,

Nitrite reductase,

Screening.

\begin{abstract}
Nitrogen fixation is considered as a significant biological process, which is important in agricultural and environmental implications. Herein denitrifying bacteria from Bahr Al-Milh Salt Lake, Karbala, Iraq, was reported using molecular and phenotypical characteristics. Samples were collected from eastern parts of the Bahr Al-Milh. The strains were grown in different saline concentrations of nutrient broth (2.5-22.5\%). Nitrate and nitrite reduction activities were assessed for all the isolates. Molecular analysis was performed by BLAST alignment and MEGA7 software. The 16S rRNA sequences of newly found strains were submitted in the GenBank database. 218 strains were isolated, $76.6 \%$ of which were nitrate reductase and $25.5 \%$ nitrate-nitrite reductase $(\mathrm{NiR})$ positive strains. $68 \%$ slightly and $32 \%$ moderately halophilic bacteria were found. Isolates with nitrite reduction activity belonged to five genera including Bacillus, Halobacillus, Idiomarina, Oceanobacillus, and Virgibacillus. The isolates with the ability of producing nitrate-NiR consisted of bacteria in genera Halobacillus and Halomonas. Apart from industrial and biotechnological applications, the present information might be useful to fertilize the saline soil for agricultural aims. The isolated strains could be considered as a source of halotolerant enzymes in agriculture and environmental implications in hypersaline areas. To the best of our knowledge, this is the first microbiological study on halophilic bacteria from Bahr Al-Milh Salt Lake.
\end{abstract}

\section{INTRODUCTION}

One of the significant characteristics of some prokaryotes is their ability to live under extreme conditions ( $\mathrm{pH}$ value, pressure, salinity, temperature, oxygen, and starving conditions) [1]. Not many microorganisms are able to tolerate large amount of salt, but a group of salt-loving bacteria have been successfully adjusted to the high concentrations of $\mathrm{NaCl}$, therefore, they are called halophilic microorganisms. They have a large diversity found in three domains of Archaea, Bacteria, and Eukarya. They mostly require above 10$15 \%$ of salt concentration for survival [2]. Hypersaline environments have a universal distribution represented mainly in aquatic areas such as coastal, deep-sea locations, salt lakes, and also saline alluvial soils [3]. Halophilic bacteria have evolved in a way they can resist rigid situations which their counterparts fail. To stand unusual saline amount, halophilic organisms have developed internal mechanisms to balance the osmotic stress of the environment and to overcome the high salinity complications leading to their functionality in such

*Corresponding Author:

Mushtaq T Sh. Al-Rubaye,

Department of Microbiology, Faculty of Biological Sciences,

Shahid Beheshti University, Tehran, Iran.

Tel.: 0098935166 9205. Fax: 00982122021355.

Email:moshtaq.amiri@gmail.com circumstances [4]. A notable example of this salt-dependent feature is the disintegration taking place in the cell envelope and consequently inactivation of membrane-bound enzymes on lowering the $\mathrm{NaCl}$ concentration. Peculiar physiology of these bacteria involving adaptation to hypersaline environments has led to the investigation of halophilic enzymes [5].

Nitrogen fixation is considered as one of the significant biological processes in soil, which is influenced by environmental factors such as $\mathrm{pH}$, temperature, and oxygen. [6]. Regarding the importance of N-cycle in agriculture and environmental implications, nitrogen metabolism of bacteria has been in the spotlight of recent years' studies [7]. In the past, the primary driving of food crops was to maximize productivity and enhance the yield potential. Nowadays, the requisite is to provide sustainability along with productivity in the long-term; therefore, it will be mandatory to reload the reserves of nutrients that are lost or removed from the soil. As for nitrogen $(\mathrm{N})$, it can be inserted into agricultural systems in the form of artificial $\mathrm{N}$-fertilizers or obtained from atmospheric $\mathrm{N}_{2}$ fixed by biological processes [8]. Soil salinity might have an effect on fertility by disrupting the activity of nitrogen turnover [6]. Majority of bacteria use nitrate as an inorganic source of nitrogen $[9,10]$. One of the strategies evolved in microorganisms living in such extreme environments is the developed enzymes capable of functioning even in salinity zones. Whenever there is a high amount of salt, and consequently the oxygen concentration is decreased below 
normal, nitrate plays the role of electron receptor instead of oxygen in dissimilatory and assimilatory metabolism. The microorganism performing this action is called denitrifier. Nitrate reductase (NR) and nitrite reductase (NiR) are the key enzymes involved in the stepwise reduction of nitrate to nitrite and the following nitrite to ammonia [11].

Bahr Al-Milh (Lake Razazah) is one of the artificial Salt Lakes located $10 \mathrm{~km}$ west of Karbala, Iraq $\left(32^{\circ} 00^{\prime}-33^{\circ} 15^{\prime} \mathrm{N}\right.$ and $\left.42^{\circ} 00^{\prime}-43^{\circ} 45^{\prime} \mathrm{E}\right)$. While the salt concentration of the lake has been rising due to rainfall shortage, temperature increase, etc., Bahr Al-Milh is considered as an extreme ecosystem with potential halophilic bacteria sources [12]. A number of eukaryotic microorganisms from Bahr Al-Milh Salt Lake were defined in previous studies $[13,14]$. However, to our knowledge, no report has been published to describe the prokaryotic diversity of the lake so far. The present study relied on culture methods. Nitratenitrite reducing halophilic bacteria was isolated and characterized using physiological, morphological, and molecular techniques.

\section{MATERIALS AND METHODS}

\subsection{Sampling and Preparations}

Fifteen water and soil samples were collected from different locations from eastern parts of the Bahr Al-Milh in February 2014. Samples were put into labeled sterile plastic tubes and bags, then transported to microbiology laboratory in $<24 \mathrm{~h}$. The temperature of the area was estimated between $20^{\circ} \mathrm{C}$ and $25^{\circ} \mathrm{C}$. The strains were cultured in different saline concentration of nutrient broth - 2.5\%, 5.0\%, 7.5\%, $10.0 \%, 12.5 \%, 15.0 \%, 17.5 \%, 20 \%$, and $22.5 \%$ - containing artificial seawater (ASW) with the following composition: $175 \mathrm{~g} \mathrm{NaCl}, 20 \mathrm{~g}$ $\mathrm{MgCl}_{2} \cdot 6 \mathrm{H}_{2} \mathrm{O}, 5 \mathrm{~g} \mathrm{~K}_{2} \mathrm{SO}_{4}$, and $0.1 \mathrm{~g} \mathrm{CaCl}_{2}$, and $2 \mathrm{~mL}$ filtered saline lake water as the source of trace elements. Final volume was then reached to $1 \mathrm{~L}$ with distilled water. The $\mathrm{pH}$ 7-8.5 was provided with the addition of $1 \mathrm{~N}$ sodium hydroxide.

The culture media were incubated at $37^{\circ} \mathrm{C}$ for a week. $1 \mathrm{~mL}$ of each sample was transferred to nutrient agar medium with the same saline concentrations where they incubated for another 1 week. The number of colonies formed was counted at day 7 following by 2 -week further incubation. Morphology of the cells was observed by light microscopy (model $\mathrm{BH} 2$; Olympus). Gram staining and $\mathrm{KOH}$ lysis tests were performed according to previous reports $[15,16]$.

\subsection{Enzymatic Activities}

To assess nitrate and nitrite reduction activities, the isolates were cultured in tubes of $1 \%$ peptone water with $0.1 \%$ potassium nitrate and $0.03 \%$ sodium nitrite, respectively. Durham tubes were placed into test tubes to allow an assessment of gas production in the media due to nitrite reduction. Test tubes were sealed with airtight screw tops, incubated for 5 days at $37^{\circ} \mathrm{C}$. A solution containing $8 \%$ sulfanilic acid and $0.5 \%$ alpha-naphthylamine in acetic acid was used to determine nitrate reduction to nitrite after forming a red color. The positive result of nitrite reduction was considered as gas production in the inverted Durham tube. Appearance of red color after addition of zinc dust indicates nitrite reduction to nongaseous products [17]. Catalase production was determined by adding a drop of $3 \%(\mathrm{v} / \mathrm{v}) \mathrm{H}_{2} \mathrm{O}_{2}$ and observing its hydrolysis and the consequent gas formation [18]. The oxidase activity was detected according to Kovacs [19]. Determination of utilization of glucose and sucrose as a sole source of carbon as well as acid production from them was measured as recommended by Ventosa et al. [20]. Nitrate and NiR producers were selected for further molecular analysis.

\subsection{Molecular Analysis}

The DNA was extracted (bioron sample preparation KitKorea) and purified. The 16S rRNA gene was amplified by polymerase chain reaction (PCR) run with two universal bacterial primers: 8F (5'AGAGTTTGATCCTGGCTCAG-3') and 1492R (5'GGTTACCTTGTTACGACTT-m3') [21]. PCR solution contained $5 \mu \mathrm{l}$ template DNA, $17 \mu \mathrm{l} \mathrm{dH}_{2} \mathrm{O}, 1 \mu \mathrm{l}$ primers, $1 \mu \mathrm{l} \mathrm{dNTP}, 0.75 \mu \mathrm{l}$ $\mathrm{MgCl}_{2}(50 \mathrm{mM}), 25 \mu \mathrm{l} \mathrm{PCR}$ amplification buffer (1X), and $2 \mathrm{U}$ Taq DNA polymerase. Amplification was carried out with Techne TC$3000 \mathrm{X}$ thermal cycler (UK) as follow: Initial denaturation at $95^{\circ} \mathrm{C}$ for $5 \mathrm{~min}$, followed by $301-\mathrm{min}$ cycles at $95^{\circ} \mathrm{C}, 30 \mathrm{~s}$ at $58^{\circ} \mathrm{C}, 1 \mathrm{~min}$ at $72^{\circ} \mathrm{C}$, and $10 \mathrm{~min}$ at $72^{\circ} \mathrm{C}$ for the final extension [22]. After electrophoresing [Figure 1], PCR products - single $1400 \mathrm{bp}$ of DNA fragments - were then purified using Gene All Gel Extraction Kit (Korea). Sequencing of 16S rRNA was performed by Macrogen Biotechnology Company (Korea) using an automated sequencer.

The newly sequenced 16S rRNA was aligned with BLAST and ribosomal database project and compared with alike bacterial sequences available in National Center for Biotechnology Information. Drawing phylogenetic trees were completed using MEGA7 software [23]; neighbor-joining [24], maximum likelihood [25], and maximumparsimony [15] algorithms were applied. Bootstrap analyses based on 1000 replications determined the confidence values of the branches. 16S rRNA sequences of newly found strains were submitted in the GenBank database [Table 1].

\section{RESULTS AND DISCUSSION}

A total of 218 strains were isolated from enrichment cultures, $76.6 \%$ of which was determined to be only NR positive, and $25.5 \%$ found to produce both nitrate and $\mathrm{NiR}$. Optimum $\mathrm{pH}$ ranged $7.0-7.5$ and optimum temperature was determined to be around $37^{\circ} \mathrm{C}$. Based on the definition of halophiles, no extremely halophilic bacteria were detected, and the frequency of slightly and moderately halophilic isolates was found to be $68 \%$ and $32 \%$, respectively [20]. The optimum salinity to favor growth was $10 \%$ ASW. They mostly consist of Grampositive bacteria $(73.8 \%, n=161)$ followed by just about one-fourth of Gram-negative bacteria $(26.2 \%, n=57)$. From morphological aspect, they included $57.8 \%(n=126)$ rods or short rods and $42.2 \%(n=92)$ cocci appearing in singles, pairs or short chains.

According to the results, almost half of the bacteria, which were capable of producing only NR were Gram-positive (53.1\%). Same frequency is obtained for nitrate- NiR positive bacteria (50.0\%). Of the bacteria with the ability of producing NR, 12 isolates were randomly selected for further molecular analysis. Four bacteria with the ability to produce gas through nitrite reduction were selected accidentally for supplemental molecular tests as well. Table 2 shows the characterization

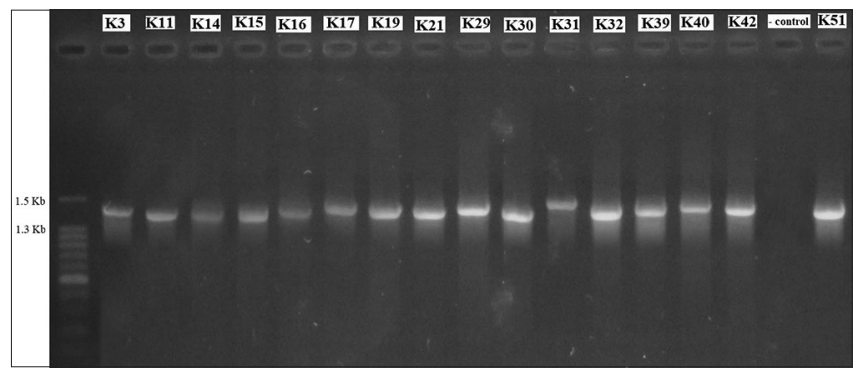

Figure 1: Agarose gel electrophoresis of the polymerase chain reaction products. 
Table 1: The accession numbers of the isolates.

\begin{tabular}{|c|c|c|c|}
\hline Strains & Accession number & Strains & Accession number \\
\hline Bacillus sp. K3 & KT59792 & Halobacillus sp. K15 & KT991680 \\
\hline Bacillus sp. K14 & KT597928 & Halobacillus sp. K16 & KT597929 \\
\hline Bacillus sp. K21 & KT200230 & Halobacillus sp. K17 & KT353098 \\
\hline Bacillus sp. K32 & KT223787 & Halobacillus sp. K51 & KT223788 \\
\hline Virgibacillus sp. K11 & KR347118 & Halomonas sp. K29 & KT353099 \\
\hline Virgibacillus sp. K19 & KT597930 & Halomonas sp. K40 & KT597931 \\
\hline Oceanobacillus sp. K30 & KT281118 & Halomonas sp. K42 & KR909223 \\
\hline Oceanobacillus sp. K31 & KT281119 & Idiomarina sp. K39 & KT200229 \\
\hline
\end{tabular}

Table 2: Phenotypic characteristics of nitrate and NiR positive isolates.

\begin{tabular}{|c|c|c|c|c|c|c|c|c|c|}
\hline \multirow[t]{2}{*}{ Strains } & \multirow[t]{2}{*}{ Gram } & \multirow[t]{2}{*}{ Oxidase } & \multirow[t]{2}{*}{ Catalase } & \multirow[t]{2}{*}{ Nitrate reduction } & \multirow[t]{2}{*}{ Nitrite reduction } & \multicolumn{2}{|c|}{$\begin{array}{l}\text { Acid production } \\
\text { from }\end{array}$} & \multicolumn{2}{|c|}{$\begin{array}{c}\text { Carbon source } \\
\text { utilization }\end{array}$} \\
\hline & & & & & & Sucrose & Glucose & Sucrose & Glucose \\
\hline Bacillus sp. K3 & + & + & + & + & - & + & + & + & + \\
\hline Bacillus sp. K14 & + & + & - & + & - & + & - & + & - \\
\hline Bacillus sp. K21 & + & - & + & + & - & - & - & - & - \\
\hline Bacillus sp. K32 & + & + & + & + & - & + & + & + & + \\
\hline Virgibacillus sp. K11 & + & + & + & + & - & - & - & - & - \\
\hline Virgibacillus sp. K19 & + & + & + & + & - & - & + & - & + \\
\hline Oceanobacillus sp. K30 & + & + & + & + & - & + & + & + & + \\
\hline Oceanobacillus sp. K31 & + & - & + & + & - & - & - & - & - \\
\hline Halobacillus sp. K15 & + & + & + & + & - & - & - & - & - \\
\hline Halobacillus sp. K16 & + & + & + & + & - & + & - & + & - \\
\hline Halobacillus sp. K17 & + & - & + & + & - & + & - & + & - \\
\hline Halobacillus sp. K51 & + & + & + & + & + & - & - & - & - \\
\hline Halomonas sp. K29 & - & - & + & + & + & - & - & - & - \\
\hline Halomonas sp. K40 & - & + & + & + & + & - & + & - & + \\
\hline Halomonas sp. K42 & - & + & + & + & + & - & - & - & - \\
\hline Idiomarina sp. K39 & - & + & + & + & - & - & + & - & + \\
\hline
\end{tabular}

NiR: nitrite reductase.

of the very strains. Catalase activity was reported for $93.7 \%$ of them, and $75.0 \%$ were positive for oxidase activity. The ability to produce acid from glucose and sucrose were observed in $37.5 \%$ and $37.5 \%$ of isolates, respectively. Similar results were obtained from using the mentioned carbohydrates as a sole source of carbon.

Based on the morphological and molecular (sequences of genes encoding for 16S rRNA) analysis, taxonomic groups of isolates were specified. Using bootstrap values, the isolates that were able to produce NR without nitrite reduction activity belonged to five different genera including Bacillus, Halobacillus, Idiomarina, Oceanobacillus, and Virgibacillus. The isolates with the ability of producing nitrate- NiR consisted of bacteria in genera Halobacillus and Halomonas. Figure 2 presents the phylogenetic trees of isolates. The 16S rRNA partial gene sequences of strains have been deposited in the GenBank database.

Recent studies have seen a surge in investigating the diversity of halophilic microorganisms in extreme environments including salt lakes [26]. Both microbiological and molecular studies have showed the presence of a great number of halophilic microorganisms in these saline environments [27-28]. Bahr Al-Milh Salt Lake on the west of city Karbala, Iraq, was made with the aim of water supply to this religious and strategic city but its saline bed and excessive water evaporation created a saline ecosystem. During recent years, apart from high salinity, drastic physico-chemical changes, extreme temperature variations, and dryness have made it a target for microbiology studies. In the present work, both molecular and microbiological tests revealed the presence of halophilic bacteria in a wide range of diversity in the Bahr Al-Milh Salt Lake. More than one-third of isolates were able to produce $\mathrm{N}$-cycle key enzymes, which indicated the potential of further studies about agricultural, industrial and biotechnological applications of this lake's microorganisms.

The BLAST results showed that the isolated bacteria were mostly belonging to genera Bacillus, Halobacillus, Halomonas, Idiomarina, Oceanobacillus, and Virgibacillus. The results concur with the study of Rohban et al. that reported Salicola as the most dominant genus in Howz Soltan Lake, Qom, Iran [29]. In addition, Bacillus, Halobacillus, Lysinibacillus, Oceanobacillus, and Virgibacillus were among the genera found in extreme environments of India [30]. The most common bacteria from different saline environments in South Spain were assigned to genus Salinivibrio [5]. This is in agreement with the earlier study on halophilic bacteria from Alborz oil field, Iran, which showed $50 \%$ of isolates, belonged to genera Halomonas [31]. 


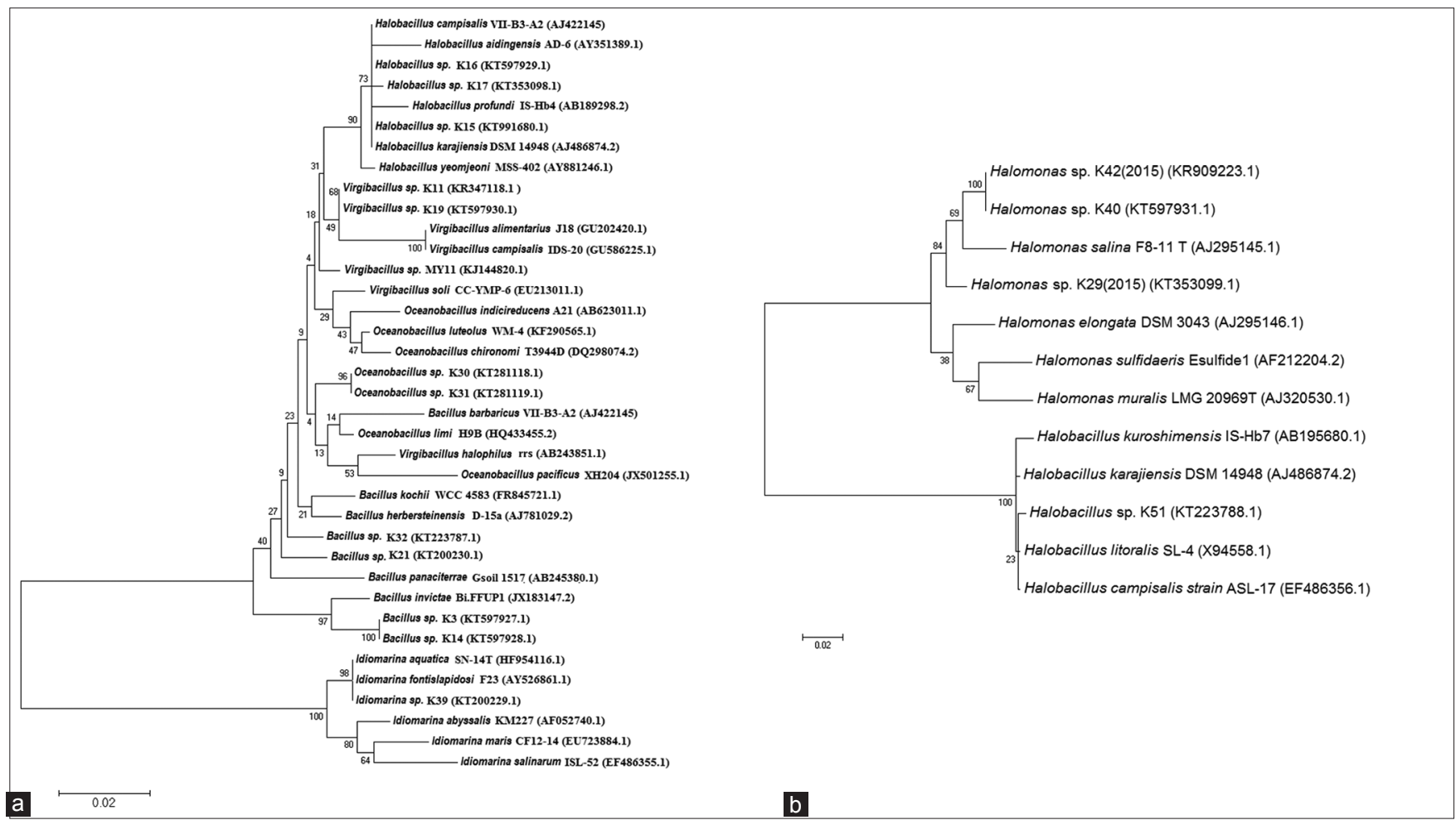

Figure 2: (a) Phylogenetic tree of the halophilic isolates with the ability of producing nitrate reductase, (b) phylogenetic tree of the halophilic isolates which are able to produce both nitrate and nitrite reductase. The trees were constructed according to the neighbor-joining method showing the position of isolates based on the partial 16S rDNA sequence comparison. The numbers of branches indicated bootstrap values and the accession numbers of the reference strains are presented in brackets.

Although species of the genus Salinivibrio can be found in low salt concentration, in this study any member of this genus was not identified [29]. The study of microbial diversity of Qinghai Lake, China, revealed Actinobacteria and Acidobacteria/Holophaga as the dominant Gram-positive bacteria while they did not find among the present isolates [32]. The member of genus Salicola was isolated from a saline spring in Mahdasht, Alborz province, Iran [33].

Totally, the number of denitrifying bacteria is fewer than that of other heterotrophs in different ecosystems; as a result, isolating or identifying of these strains seems to be more difficult than other ones. According to Li et al. [34], aerobic denitrifying bacteria can be isolated from activated sludge sampled from sewage disposal. A number of studies examined denitrifying bacteria for usage in the development of a bioprocess that could potentially restore the function of ion-exchanges agents. For instance, a moderately haloalkalophilic denitrifying bacterium belongs to genus Halomonas was isolated from a series of saline-alkaline lakes located in Grant County, Washington State [35]. Study of a member of Pseudomonas genus, isolated from a sample of crude oil, Pembina oilfield, Canada, showed a significant increase of $\mathrm{Fe}(\mathrm{II})$ during short incubation in association with increased production and accumulation of nitrite [36]. Apart from the abovementioned application of denitrifying microorganisms, these bacteria can be applied for treating wastewaters containing $\mathrm{NH}_{4}^{+}$or $\mathrm{NO}_{3}$-at high concentrations and those carrying the very ions [37].

\section{CONCLUSION}

The present information might be useful for industrial microbiologists, biotechnologists, and others who are interested in fertilizing saline soil for agricultural purposes. In addition, the isolated strains could be considered as a source of halotolerant enzymes in agriculture and environmental implications in hypersaline areas.

\section{REFERENCES}

1. de Lourdes Moreno M, Pérez D, García MT, Mellado E. Halophilic bacteria as a source of novel hydrolytic enzymes. Life (Basel) 2013;3:38-51.

2. Ventosa A, Nieto JJ, Oren A. Biology of moderately halophilic aerobic bacteria. Microbiol Mol Biol Rev 1998;62:504-44.

3. Andrei AŞ, Banciu HL, Oren A. Living with salt: Metabolic and phylogenetic diversity of Archaea inhabiting saline ecosystems. FEMS Microbiol Lett 2012;330:1-9.

4. Bonete MJ, Martínez-Espinosa RM. Enzymes from halophilic Archaea: Open questions. In: Ventosa A, Oren A, Ma Y, editors. Halophiles and Hypersaline Environments. Berlin: Springer-Verlag Berlin Heidelberg. Inc.; 2011. p. 359-71.

5. Sánchez-Porro C, Martín S, Mellado E, Ventosa A. Diversity of moderately halophilic bacteria producing extracellular hydrolytic enzymes. J Appl Microbiol 2003;94:295-300.

6. Zahran HH, Ahmad MS, Afkar EA. Isolation and characterization of nitrogen-fixing moderate halophilic bacteria from saline soils of Egypt. J Basic Microbiol 1995;35:269-75.

7. Cabello P, Roldán MD, Moreno-Vivián C. Nitrate reduction and the nitrogen cycle in Archaea. Microbiology 2004;150:3527-46.

8. Peoples MB, Herridge DF, Ladha JK. Biological nitrogen fixation: An efficient source of nitrogen for sustainable agricultural production? Plant and Soil 1995;174:3-28.

9. Lin JT, Stewart V. Nitrate assimilation by bacteria. Adv Microb Physiol 1998;39:1-30, 379.

10. Moreno-Vivián C, Cabello P, Martínez-Luque M, Blasco R, Castillo F. Prokaryotic nitrate reduction: Molecular properties and 
functional distinction among bacterial nitrate reductases. J Bacteriol 1999;181:6573-84.

11. Martínez-Espinosa RM, Marhuenda-Egea FC, Bonete MJ. Assimilatory nitrate reductase from the haloarchaeon Haloferax mediterranei: Purification and characterization. FEMS Microbiol Lett 2001;204:381-5.

12. Rahi KA, Halihan T. Changes in the salinity of the Euphrates river system in Iraq. Regional Environl Change 2010;10:27-35.

13. Kornijów R, Szczerbowski JA, Krzywosz T, Bartel R. The macrozoobenthos of the Iraqi lakes Tharthar, Habbaniya and Razzazah. Arch Pol Fish 2011;9:127-45.

14. Salman JM, Nasser AJ. Variation of some physicochemical parameters and biodiversity of gastropods species in Euphrates river, Iraq. Int J Environ Sci Dev 2013;5:328-31.

15. Fitch WM. Toward defining the course of evolution: Minimum change for a specific tree topology. Syst Zool 1971;20:406-16.

16. Vahed SZ, Forouhandeh H, Hassanzadeh S, Klenk HP, Hejazi MA, Hejazi MS, et al. Isolation and characterization of halophilic bacteria from Urmia lake in Iran. Mikrobiologiia 2011;80:826-33.

17. Bøver K, Henriksen SD. Minimal standards for description of new taxa within the genera moraxella and acinetobacter: Proposal by the subcommittee on Moraxella and allied bacteria. Int J Syst Evol Microbiol 1976;26:92-6.

18. Bradshaw LJ. Laboratory Microbiology. $4^{\text {th }}$ ed. San Diego, California: Fort Worth, TX: Saunders College Publishing; 1992.

19. Kovacs N. Identification of Pseudomonas pyocyanea by the oxidase reaction. Nature 1956;178:703-4.

20. Ventosa A, Quesada E, Rodri'guez-Valera F, Ruiz-Berraquero F, Ramos-Cormenzana A. Numerical taxonomy of moderately halophilic Gram-negative rods. J Gen Microbiol 1982;128:1959-68.

21. Sh AM, Al-Musawi MH, Fakhari J, Hosseini M. Screening and characterization of halophilic bacteria with industrial enzymes from salt lake razazah, Karbala, Iraq. Biosci Biotech Res Asia 2017;14:531-9.

22. Hosseini M, Babaha F, Sh AM, Fakhari J, Al-Musawi MH. Ureaseproducing halophilic bacteria isolated from bahr Al-Milh salt lake, Karbala, Iraq. J Pure Appl Microbiol 2017;11:711-6.

23. Tamura K, Stecher G, Peterson D, Filipski A, Kumar S. MEGA6: Molecular evolutionary genetics analysis version 60. Mol Biol Evol 2013;30:2725-9.

24. Saitou N, Nei M. The neighbor-joining method: A new method for reconstructing phylogenetic trees. Mol Biol Evol 1987;4:406-25.

25. Felsenstein J. Evolutionary trees from DNA sequences: A maximum likelihood approach. J Mol Evol 1981;17:368-76.

26. Oren A. Molecular ecology of extremely halophilic Archaea and bacteria. FEMS Microbiol Ecol 2002;39:1-7.

27. Demergasso C, Casamayor EO, Chong G, Galleguillos P, Escudero L, Pedros-Alio CC. Distribution of prokaryotic genetic diversity in athalassohaline lakes of the Atacama Desert, Northern Chile. FEMS Microbiol Ecol 2004;48:57-69.

28. Cayol JL, Ollivier B, Patel BK, Prensier G, Guezennec J, Garcia JL, et al. Isolation and characterization of halothermothrix orenii gen. Nov. sp. Nov. a halophilic, thermophilic, fermentative, strictly anaerobic bacterium. Int J Syst Bacteriol 1994;44:534-40.

29. Rohban R, Amoozegar MA, Ventosa A. Screening and isolation of halophilic bacteria producing extracellular hydrolyses from Howz Soltan lake, Iran. J Ind Microbiol Biotechnol 2009;36:333-40.

30. Yadav AN, Verma P, Kumar M, Pal KK, Dey R, Gupta A, et al. Diversity and phylogenetic profiling of niche-specific Bacilli from extreme environments of India. Ann Microbiol 2015;65:611-29.

31. Hosseini M, Fakhari J, Sh AM, Dezfouli EA. Screening of halophilic bacteria able to degrade crude oil contamination from Alborz oil field, Qom, Iran. J Pure Appl Microbiol 2017;11:773-8.

32. Dong H, Zhang G, Jiang H, Yu B, Chapman LR, Lucas CR, et al. Microbial diversity in sediments of saline Qinghai lake, china: Linking geochemical controls to microbial ecology. Microb Ecol 2006;51:65-82.

33. Sh AM, Fakhari J, Hosseini M, Bakhtiari A. Salicola mahdashtensis sp. nov., an extremely halophilic bacterium isolated from Mahdasht saline spring in Iran. Microbiology 2017;86:213-7.

34. Li CN, $\mathrm{Lu} \mathrm{XW}, \mathrm{Yu} \mathrm{B}$. Research on simultaneous nitrification and denitrifying. Water Wastewater Eng 2001;27:22-4.

35. Mormile MR, Romine MF, Garcia MT, Ventosa A, Bailey TJ, Peyton BM, et al. Halomonas campisalis sp. Nov. a denitrifying, moderately haloalkaliphilic bacterium. Syst Appl Microbiol 1999;22:551-8.

36. Obuekwe CO, Westlake DW, Cook FD. Effect of nitrate on reduction of ferric iron by a bacterium isolated from crude oil. Can J Microbiol 1981;27:692-7.

37. Zhou Q, Takenaka S, Murakami S, Seesuriyachan P, Kuntiya A, Aoki K, et al. Screening and characterization of bacteria that can utilize ammonium and nitrate ions simultaneously under controlled cultural conditions. J Biosci Bioeng 2007;103:185-91.

\footnotetext{
How to cite this article:

Hosseini M, Al-Rubaye MTS, Fakhari J, Babaha F. Isolation and

characterization of denitrifying halophilic bacteria from Bahr Al-Milh Salt

Lake, Karbala, Iraq. J App Biol Biotech. 2018;6(04):32-36.

DOI: 10.7324/JABB.2018.60406.
} 